\title{
PENGARUH BERBAGAI PH SARI BUAH DAN SUHU PASTEURISASI TERHADAP AKTIVITAS ANTIOKSIDAN DAN TINGKAT PENERIMAAN SARI KULIT BUAH MANGGIS
}

\author{
Claudia Norma Gupita, Arintina Rahayuni ${ }^{*}$ \\ Program Studi Ilmu Gizi Fakultas Kedokteran Universitas Diponegoro \\ Jl.Dr.Sutomo No.14, Semarang, Telp (024) 8453708, Email : gizifk@undip.ac.id
}

\begin{abstract}
Background: Oxidative stress is associated with the progression of degenerative disease. The consumption of antioxidant resources to prevent the body from oxidative stress damage. Mangosteen fruit hull is one of the mangosteen waste which has potential activity of natural antioxidant, such as xanthone and anthocyanins. Xanthon and anthocyanins influenced by $\mathrm{pH}$ and heating. Therefore, it is necessary to study about the effect of $\mathrm{pH}$ and temperature pasteurized on antioxidant activity of the mangosteen fruit hull juice.

Objective : Analyze the effect of antioxidant activity and the level of acceptance of the mangosteen fruit hull juice with various $\mathrm{pH}$ and pasteurization temperature.

Methods : An experimental study with a factorial design which combines $\mathrm{pH}$ (pH 3 and $\mathrm{pH} 4$ ) and pasteurization temperature (temperature of $75^{\circ} \mathrm{C}, 85^{\circ} \mathrm{C}, 95^{\circ} \mathrm{C}$ ). The analyzes are antioxidant activities and the level of acceptance. The antioxidant activity obtained with DPPH (2,2 dhipenyl -1-pycrilhidrazyil) test. The acceptance test are conducted with hedonic test. Statistical analysis of the antioxidant activity using Two Way ANOVA test CI 95\%, while the level of acceptance using Friedman test followed Wilcoxon test.

Result : The result of antioxidant activity of mangosteen fruit hull juice ranged 80.64-89.70\%. The various pH and pasteurization temperature did not effect the antioxidant activity of the mangosteen fruit hull juice. The results of test acceptance, color and taste are affected by variations in $\mathrm{pH}$ and temperature pasteurization, except aroma. The more acidic pH of juice, mangosteen fruit hull juice color of the panelists preferred. Acidification can not relieve harsh flavor mangosteen fruit hull juice. All mangosteen fruit hull juice aroma panelists preferred.

Conclucion : The various $\mathrm{pH}$ and pasteurization temperature did not effect the antioxidant activity of the mangosteen fruit hull juice. The results of test acceptance, color and taste are affected by variations in $\mathrm{pH}$ and temperature pasteurization, except aroma.
\end{abstract}

Keyword : antioxidant activity; mangosteen fruit hull juice; $\mathrm{pH}$; pasteurization temperature

\begin{abstract}
ABSTRAK
Latar Belakang : Stres oksidatif dihubungkan dengan perkembangan penyakit degeneratif. Konsumsi sumber antioksidan dapat melindungi tubuh dari kerusakan stres oksidatif. Kulit buah manggis merupakan salah satu limbah buah manggis yang potensial memiliki aktivitas antioksidan alami, seperti xanton dan antosianin. Xanton dan antosianin dipengaruhi oleh $\mathrm{pH}$ dan pemanasan. Oleh karena itu, perlu dilakukan penelitian tentang pengaruh pH sari buah dan suhu pasteurisasi terhadap aktivitas antioksidan sari kulit buah manggis.

Tujuan : Menganalisis pengaruh aktivitas antioksidan dan tingkat penerimaan sari kulit buah manggis dengan variasi pH sari buah dan suhu pasteurisasi.

Metode: Merupakan penelitian eksperimental dengan rancangan faktorial yaitu mengkombinasikan pH sari buah ( $\mathrm{pH} 3$ dan $\mathrm{pH}$ 4) dan suhu pasteurisasi (suhu $75^{\circ} \mathrm{C}, 85^{\circ} \mathrm{C}, 95^{\circ} \mathrm{C}$ ). Analisis yang dilakukan adalah aktivitas antioksidan dan tingkat penerimaan. Aktivitas antioksidan didapatkan dengan uji DPPH (2,2 dhipenyl -1pycrilhidrazyil). Tingkat penerimaan dilakukan dengan uji hedonik. Analisis statistik data aktivitas antioksidan menggunakan uji Two Ways ANOVA CI 95\%, sedangkan data tingkat penerimaan menggunakan uji Friedman dilanjutkan uji Wilcoxon.

Hasil : Hasil aktivitas antioksidan sari kulit buah manggis berkisar 80.64-89.70\%. Variasi pH dan suhu pasteurisasi tidak mempengaruhi aktivitas antioksidan sari kulit buah manggis. Hasil dari uji tingkat penerimaan, warna dan rasa dipengaruhi oleh variasi pH dan suhu pasteurisasi, kecuali aroma. Semakin asam, warna sari kulit buah manggis makin disukai. Pengasaman tidak dapat menghilangkan rasa sepat pada sari kulit buah manggis. Semua aroma sari kulit buah manggis disukai panelis.

Simpulan : Aktivitas antioksidan sari kulit buah manggis tidak dipengaruhi oleh variasi pH dan suhu pasteurisasi. Hasil uji tingkat penerimaan, warna dan rasa dipengaruhi oleh variasi $\mathrm{pH}$ dan suhu pasteurisasi, kecuali aroma.
\end{abstract}

Kata Kunci : aktivitas antioksidan; sari kulit buah manggis; pH; suhu pasteurisasi

${ }^{*}$ Penulis Penanggungjawab 


\section{PENDAHULUAN}

Stress oksidatif merupakan kondisi terjadinya peningkatan radikal bebas yang menyebabkan kerusakan sel, jaringan atau organ. Stres oksidatif berhubungan dengan perkembangan penyakit degeneratif seperti kanker, kardiovaskuler, dan stroke. $^{1}$ Berdasarkan Riskesdas 2007, prevalensi di Jawa Tengah pada penyakit tumor dan kanker mencapai $8,1 \%$, penyakit jantung mencapai $0,8 \%$, dan stroke mencapai $5,7 \% .^{2}$

Antioksidan memiliki kemampuan untuk menetralisasi radikal bebas, sehingga mampu melindungi tubuh dari kerusakan stres oksidatif dan menghambat terjadinya penyakit degeneratif. ${ }^{3}$ Antioksidan banyak ditemukan pada sayur dan buah. $^{4}$ Kulit buah manggis merupakan salah satu limbah buah manggis yang potensial memiliki aktivitas antioksidan alami. ${ }^{5}$

Buah manggis (Garcinia mangostana L.) merupakan salah satu buah tropis yang digemari masyarakat Indonesia. Umumnya masyarakat mengkonsumsi buahnya saja, sedangkan kulitnya dibuang. Pada masa panen, limbah kulit buah manggis menjadi melimpah dan terbuang sia-sia. Padahal limbah tersebut dapat dimanfaatkan menjadi produk makanan atau minuman serta obatobatan. Di dalam kulit buah manggis terkandung nutrisi, seperti karbohidrat $(82,50 \%)$, protein(3,02\%), dan lemak $(6,45 \%)$. Selain itu, kulit buah manggis juga mengandung senyawa yang berperan sebagai antioksidan seperti antosianin $(5,7-6,2 \mathrm{mg} / \mathrm{g})$, xanton dan turunannya $(0,7-34,9 \mathrm{mg} / \mathrm{g}){ }^{6}{ }^{6}$ Penelitian Weecharangsan et al. menunjukkan bahwa ekstrak kulit buah manggis mempunyai potensi penangkap radikal bebas. ${ }^{5}$ Selain itu, kulit buah manggis memiliki manfaat sebagai antikanker, pengobatan penyakit jantung, antiinflamasi, antibakteri, dan anti-aging. ${ }^{7,8,9}$

Salah satu pemanfaatan kulit buah manggis adalah dengan pembuatan minuman sari buah. Senyawa yang berperan sebagai antioksidan seperti xanton dan antosianin memiliki sifat larut dalam air. ${ }^{10}$ Oleh karena itu, pembuatan sari kulit manggis diharapkan dapat mempertahankan manfaat dari senyawa tersebut. Minuman sari buah adalah minuman yang dibuat dari sari buah dan air dengan atau tanpa penambahan gula dan bahan tambahan makanan yang diijinkan, seperti asam sitrat. $^{11}$

Kualitas sari buah dipengaruhi oleh bahan baku yang digunakan dan proses pembuatannya. Tanin yang terkandung dalam kulit buah manggis menyebabkan rasa sepat. ${ }^{12}$ Pengaturan $\mathrm{pH}$ pada sari buah adalah salah satu upaya untuk menurunkan kadar tanin pada kulit buah manggis, yaitu pada $\mathrm{pH}$ asam $(\mathrm{pH}=3) .{ }^{13}$ Pengaturan $\mathrm{pH}$ pada sari buah dengan menambahkan asam sitrat. ${ }^{14}$ Antosianin pada kulit buah manggis menyebabkan warna menjadi merah keunguan. Pada $\mathrm{pH}$ asam, warna antosianin berubah menjadi semakin merah. Xanton pada kulit buah manggis memberikan warna kuning. Kedua pigmen alami ini akan mempengaruhi warna sari kulit buah manggis yang akan dihasilkan. ${ }^{10}$ Suhu pasteurisasi juga mempengaruhi senyawa antioksidan pada kulit buah manggis. Antosianin mudah rusak karena pemanasan, sehingga dapat menurunkan bioaktivitasnya. ${ }^{15}$ Sedangkan xanton memiliki sifat tahan panas. ${ }^{10}$ Oleh karena itu, pengaturan suhu pemanasan yang tepat dapat mengurangi kerusakan senyawa antioksidan pada sari kulit buah manggis.

Berdasarkan latar belakang di atas, maka perlu dilakukan penelitian mengenai pengaruh $\mathrm{pH}$ dan suhu pasteurisasi terhadap aktivitas antioksidan dan tingkat penerimaan pada sari kulit buah manggis.

\section{METODE}

Penelitian ini merupakan penelitian dalam bidang food production. Penelitian dilakukan di Laboratorium Teknologi Pangan Politeknik Kesehatan Semarang dan Laboratorium Ilmu Pangan Fakultas Teknologi Pertanian Universitas Katholik Soegijapranata Semarang pada bulan Juni hingga Juli 2012.

Penelitian ini merupakan penelitian eksperimental dengan rancangan faktorial yaitu faktor pertama $\mathrm{pH}$ sari buah $(\mathrm{P})$ terdiri dari dua taraf $\left(\mathrm{p}_{1}=\mathrm{pH} 3, \mathrm{p}_{2}=\mathrm{pH} 4\right)$ dan faktor kedua suhu pasteurisasi (S) terdiri dari tiga taraf $\left(\mathrm{s}_{1}=75^{\circ} \mathrm{C}, \mathrm{s}_{2}\right.$ $=85^{\circ} \mathrm{C}, \mathrm{s}_{3}=95^{\circ} \mathrm{C}$ ) dengan ulangan tiga kali.

Bahan yang digunakan dalam penelitian ini adalah buah manggis (Garcinia Mangostana L.) yang diperoleh dari Jawa Timur, asam sitrat teknis yang diperoleh dari toko indra sari, dan gula tebu putih komersial dengan merek "GULAKU". Sari kulit buah manggis dibuat dengan metode sebagai berikut: pencucian kulit buah manggis menggunakan air mengalir, pemblansiran kulit mengunakan metode hot water blanching dengan suhu $80^{\circ} \mathrm{C}$ selama 3 menit, dan pemblenderan kulit manggis dan air dengan perbandingan 1: 4 (kulit manggis : air minum). Bubur kulit manggis yang dihasilkan kemudian diperas menggunakan kain saring. Lalu penambahan asam sitrat pada sari kulit buah manggis sampai $\mathrm{pH}$ yang ditentukan dan didiamkan selama 7 jam hingga endapan terpisah 
dengan cairan. Cairan sari kulit buah manggis yang diperoleh ditambahkan gula, kemudian diaduk hingga homogen. Selanjutnya sari kulit buah manggis dibotolkan dan dipasteurisasi dengan waterbath.

Data yang dikumpulkan yaitu aktivitas antioksidan dan tingkat penerimaan sari kulit buah manggis. Aktivitas antioksidan diuji menggunakan metode DPPH (2,2 dhipenyl -1-pycrilhidrazyil). Tingkat penerimaan menggunakan uji hedonik terhadap warna, aroma, dan rasa sari kulit buah manggis. Uji dilakukan pada 20 panelis agak terlatih dari mahasiswa semester VIII Program Studi Ilmu Gizi Universitas Diponegoro Semarang menggunakan 4 skala penilaian yaitu $1=$ sangat tidak suka, 2 = tidak suka, $3=$ suka, $4=$ sangat suka.
Pengaruh variasi $\mathrm{pH}$ dan suhu pasteurisasi terhadap aktivitas antioksidan sari kulit buah manggis diuji statistik menggunakan ANOVA (Analysis of Varians) two ways dengan derajat kepercayaan 95\%, sedangkan tingkat penerimaan diuji dengan Friedman dengan kepercayaan 95\% yang dilanjutkan uji posthoc Wilxocon untuk mengetahui beda nyata antar perlakuan.

\section{HASIL}

1. Aktivitas Antioksidan

Aktivitas antioksidan sari kulit buah manggis diuji menggunakan metode DPPH. Hasil analisis aktivitas antioksidan sari kulit buah manggis dengan variasi $\mathrm{pH}$ dan suhu pasteurisasi dapat dilihat pada Lampiran 3 dan secara singkat dapat dilihat pada Tabel 1.

Tabel 1. Hasil Uji Aktivitas Antioksidan Sari Kulit Buah Manggis dengan Variasi pH dan Suhu Pasteurisasi

\begin{tabular}{ccc}
\hline & Perlakuan & Aktivitas Antioksidan (\%) \\
\hline $\mathrm{pH} 3$ & Suhu pasteurisasi & $80.64 \pm 3.64$ \\
& $75^{\circ} \mathrm{C}$ & $81.84 \pm 6.85$ \\
& Suhu pasteurisasi & \\
& $85^{\circ} \mathrm{C}$ & $85.61 \pm 7.17$ \\
& Suhu pasteurisasi & \\
pH 4 & $95^{\circ} \mathrm{C}$ & $81.31 \pm 7.53$ \\
& Suhu pasteurisasi & \\
& $75^{\circ} \mathrm{C}$ & $89.70 \pm 5.39$ \\
& Suhu pasteurisasi & $85^{\circ} \mathrm{C}$ \\
& Suhu pasteurisasi & $83.38 \pm 14.32$ \\
& $95^{\circ} \mathrm{C}$ & $\mathrm{p}=0.563^{*}$ \\
\hline
\end{tabular}

Keterangan : tanda $*=$ nilai $\mathrm{p}$ interaksi variasi $\mathrm{pH}$ dan suhu pasteurisasi terhadap aktivitas antioksidan sari kulit buah manggis.

Aktivitas Antioksidan sari kulit buah manggis dengan variasi $\mathrm{pH}$ dan suhu pasteurisasi berkisar antara 80.64-89.70\%. Aktivitas antioksidan tertinggi pada sari kulit buah manggis dengan $\mathrm{pH} 4$ dan suhu pasteurisasi $85^{\circ} \mathrm{C}$. Analisa statistik dengan Anova two ways menunjukkan bahwa tidak ada pengaruh dari variasi $\mathrm{pH}$ $(\mathrm{p}=0.597)$, variasi suhu pasteurisasi $(\mathrm{p}=0.590)$, serta interaksi variasi $\mathrm{pH}$ dan suhu pasteurisasi terhadap aktivitas antioksidan sari kulit buah manggis $(\mathrm{p}=0.563)$.

2. Tingkat Penerimaan

Tingkat penerimaan sari kulit buah manggis dengan variasi $\mathrm{pH}$ dan suhu pasteurisasi didapatkan dengan uji hedonik (kesukaan). Uji hedonik meliputi warna, aroma, dan rasa. Hasil tingkat penerimaan sari kulit buah manggis dapat dilihat pada Lampiran 6 dan secara singkat dapat dilihat pada Tabel 2.

Tabel 2. Hasil Uji Kesukaan Sari Kulit Buah Manggis dengan variasi pH dan suhu pasteurisasi

\begin{tabular}{|c|c|c|c|c|c|c|}
\hline \multirow[t]{2}{*}{ Perlakuan } & \multicolumn{2}{|c|}{ Warna } & \multicolumn{2}{|c|}{ Aroma } & \multicolumn{2}{|c|}{ Rasa } \\
\hline & Rerata & Ket & Rerata & Ket & Rerata & Ket \\
\hline $\mathrm{pH}$ 3_ suhu & $3.20 \pm 0.52^{\mathrm{a}}$ & Suka & $2.55 \pm 0.68$ & Suka & $1.40 \pm 0.59^{\mathrm{d}}$ & $\mathrm{Sa}$ \\
\hline
\end{tabular}




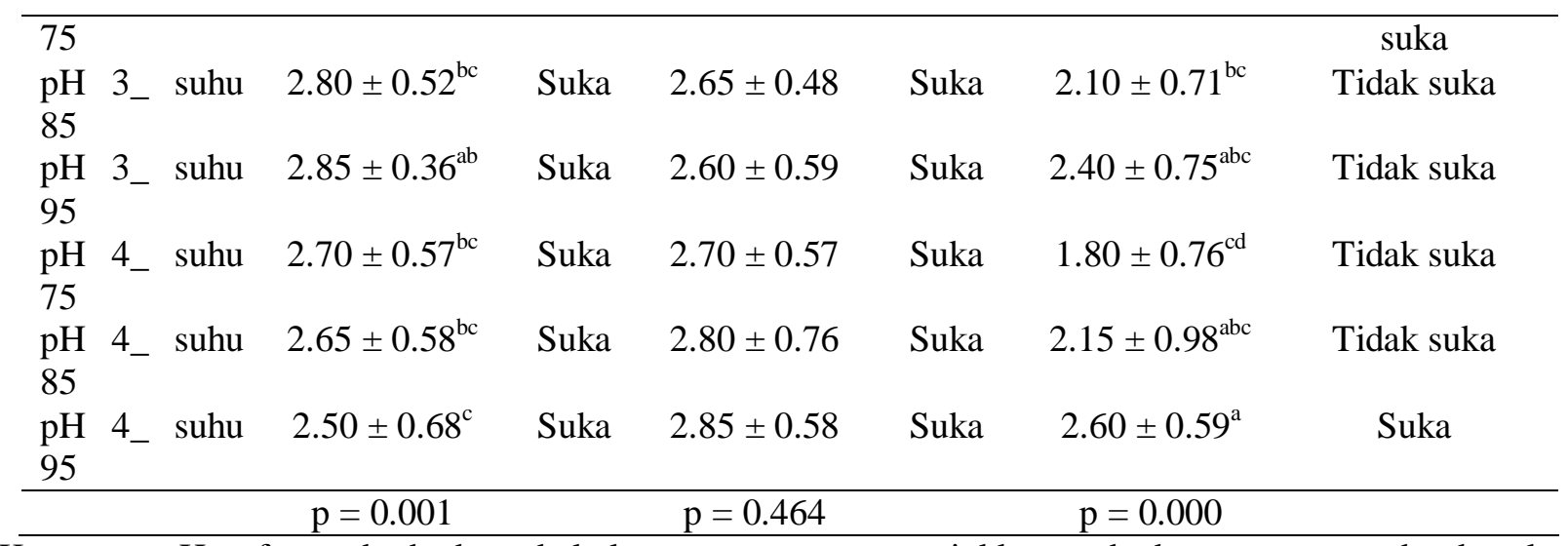

Keterangan:Huruf yang berbeda pada kolom yang sama menunjukkan perbedaan yang nyata berdasarkan uji lanjut wilcoxon $\alpha=5 \%$

Hasil tingkat penerimaan warna sari kulit buah manggis memiliki nilai rerata 2.50-3.20. Semua variasi $\mathrm{pH}$ dan suhu pasteurisasi terhadap warna sari kulit buah manggis disukai panelis. Warna sari kulit buah manggis dengan $\mathrm{pH} 3$ dan suhu pasteurisasi $75^{\circ} \mathrm{C}$ paling disukai panelis. Berdasarkan analisa statistik, variasi $\mathrm{pH}$ dan suhu pasteurisasi tidak mempengaruhi warna sari kulit buah manggis $(\mathrm{p}=0.001)$. Uji Wilcoxon menunjukkan ada perbedaan yang bermakna dari warna sari kulit buah manggis dengan variasi $\mathrm{pH}$ dan suhu pasteurisasi. Perbedaan warna sari kulit buah manggis dapat diliihat pada Tabel 2 .

Hasil tingkat penerimaan parameter aroma menunjukkan bahwa tidak ada pengaruh dari variasi $\mathrm{pH}$ dan suhu pasteurisasi terhadap aroma sari kulit buah manggis $(\mathrm{p}=0.464)$. Nilai rerata tingkat penerimaan parameter aroma yaitu 2.55 2.85. Semua variasi $\mathrm{pH}$ dan suhu pasteurisasi terhadap aroma sari kulit buah manggis disukai panelis. Aroma sari kulit buah manggis yang paling disukai yaitu sari kulit buah manggis dengan $\mathrm{pH} 4$ dan suhu pasteurisasi $95^{\circ} \mathrm{C}$

Hasil rerata tingkat penerimaan rasa sari kulit buah manggis adalah 1.40-2.60. Pada dasarnya, semua rasa sari kulit buah manggis memiliki after taste yaitu rasa sepat, namun rasa sepat pada sari kulit buah manggis dengan $\mathrm{pH} 4$ dan suhu pasteurisasi $95^{\circ} \mathrm{C}$ masih dapat ditoleransi oleh panelis. Berdasarkan analisa statistik, variasi $\mathrm{pH}$ dan suhu pasteurisasi mempengaruhi kesukaan rasa sari kulit buah manggis $(\mathrm{p}=0.000)$. Uji lanjut Wilcoxon menunjukkan ada perbedaan yang bermakna dari rasa sari kulit buah manggis dengan variasi $\mathrm{pH}$ dan suhu pasteurisasi. Perbedaan rasa sari kulit buah manggis dapat diliihat pada Tabel 2 .

\section{PEMBAHASAN}

1. Aktivitas Antioksidan

Kulit buah manggis potensial memiliki aktivitas antioksidan. ${ }^{6}$ Aktivitas antioksidan pada sari kulit buah manggis diperoleh dari senyawa fenol yang terkandung dalam kulit buah manggis seperti, xanton, antosianin, serta senyawa fenol lainnya. ${ }^{5}$ Fenol termasuk antioksidan primer. Antioksidan primer adalah antioksidan yang bereaksi dengan radikal bebas untuk menghasilkan produk yang memiliki kestabilan termodinamis yang lebih baik. Kemampuan mendonorkan atom hidrogen pada radikal menjadi ukuran kemampuan fenol sebagai antioksidan dalam menangkap senyawa radikal bebas., ${ }^{3,4}$ Hasil aktivitas antioksidan didapatkan dari uji DPPH, uji yang biasa digunakan untuk mengetahui aktivitas antioksidan makanan ataupun ekstrak dengan menggunakan larutan 2,2 dhipenyl -1pycrilhidrazyil. ${ }^{16}$ Berdasarkan hasil uji DPPH, sari kulit buah manggis mempunyai kemampuan menangkap radikal DPPH.

Aktivitas antioksidan sari kulit buah manggis dengan variasi $\mathrm{pH}$ dan suhu pasteurisasi berkisar antara 80.64-89.70\%. Apabila dibandingkan dengan aktivitas antioksidan asam askorbat, aktivitas antioksidan pada sari kulit buah manggis setara dengan larutan asam askorbat 200 ppm (84.30\%). Hasil uji DPPH pada larutan asam askorbat dapat dilihat pada Lampiran 4. Berdasarkan AKG (Angka Kecukupan Gizi) vitamin $\mathrm{C}$ pada anak-anak dan dewasa, sari kulit buah manggis yang dapat dikonsumsi yaitu sebanyak $225 \mathrm{ml}$ dan $300 \mathrm{ml}$.

Variasi $\mathrm{pH}$, suhu pasteurisasi, serta interaksi $\mathrm{pH}$ dan suhu pasteurisasi tidak mempengaruhi aktivitas antioksidan sari kulit buah manggis. Hal ini disebabkan oleh xanton memiliki sifat tahan akan panas, sehingga suhu pasteurisasi 
$75^{\circ} \mathrm{C}, 85^{\circ} \mathrm{C}$, dan $95^{\circ} \mathrm{C}$ diduga tidak merusak xanton dan bioaktivitasnya. ${ }^{10,12}$ Selain itu, xanton merupakan senyawa utama dalam kandungan kulit buah manggis, sehingga xanton sangat berperan sebagai antioksidan pada sari kulit buah manggis. Dari semua senyawa yang terkandung dalam kulit buah manggis, senyawa yang potensial menunjukkan aktivitas antioksidan adalah alphamangostin dan gamma-mangostin. ${ }^{17}$ Selain xanton, antosianin merupakan senyawa yang potensial memiliki aktivitas antioksidan. ${ }^{18}$ Tetapi antosianin memiliki sifat tidak tahan panas. ${ }^{12}$ Suhu pateurisasi yang tinggi yaitu $75^{\circ} \mathrm{C}, 85^{\circ} \mathrm{C}, 95^{\circ} \mathrm{C}$ selama 12 menit, dapat merusak senyawa antosianin dan menurunkan bioaktivitasnya. ${ }^{19}$

Senyawa antosianin memiliki sifat stabil pada suasana asam. ${ }^{12} \mathrm{pH} 3$ dan $\mathrm{pH} 4$ termasuk dalam $\mathrm{pH}$ asam. Pada $\mathrm{pH}$ asam, antosianin lebih stabil dan bioaktivitasnya dalam mendonorkan hidrogen meningkat. ${ }^{20}$ Namun suhu pasteurisasi yang tinggi menurunkan bioaktivitasnya sebagai antioksidan. Sementara itu, perlakuan $\mathrm{pH}$ asam tidak mempengaruhi senyawa xanton dan bioaktivitasnya. Hal ini dikarenakan $\mathrm{pH}$ awal sari kulit buah manggis asam dan tidak merusak senyawa xanton. Selain itu, senyawa fenol lainnya seperti tanin juga menyumbangkan kemampuannya sebagai aktivitas antioksidan. ${ }^{5,10}$

2. Tingkat Penerimaan

a. Warna

Warna yang dihasilkan sari kulit buah manggis adalah jingga kemerahan. Warna sari kulit buah manggis dipengaruhi oleh pigmen alami yang terdapat pada kulit buah manggis dan $\mathrm{pH}$. Warna jingga kemerahan ini merupakan pengaruh dari xanton yang mempunyai warna kuning dan antosianin yang mempunyai warna merah keunguan. ${ }^{12}$ Warna sari kulit buah manggis dengan $\mathrm{pH} 3$ memiliki warna jingga kemerahan yang lebih pekat dibandingkan $\mathrm{pH}$ 4. Semakin asam $\mathrm{pH}$ sari kulit buah manggis, maka warna merah semakin pekat. ${ }^{12}$ Perubahan warna ini dikarenakan perubahan struktur molekul dari antosianin sesuai dengan $\mathrm{pH}$ sehingga terbentuk isomer yang baru yang memiliki sifat gugus kromofor (gugus pembawa warna) yang berbeda dari senyawa sebelumnya. Pada $\mathrm{pH}$ asam, terjadi kenaikan jumlah gugus metoksil dan struktur utama antosianin berada dalam bentuk kation flavilium yang berwarna merah. Jumlah gugus metoksil dan kation flavilium yang mendominasi dapat menyebabkan warna menjadi lebih kemerahan. ${ }^{21}$

Variasi $\mathrm{pH}$ dan suhu pasteurisasi mempengaruhi tingkat kesukaan warna sari kulit buah manggis dan ada perbedaan warna pada masing-masing sari kulit buah manggis. Hal ini karena sari kulit buah manggis dengan $\mathrm{pH} 3$ warna jingga kemerahannya lebih pekat daripada $\mathrm{pH} 4$. Panelis lebih menyukai warna sari kulit buah manggis dengan $\mathrm{pH} 3$ dari pada $\mathrm{pH}$ 4. Sari kulit buah yang paling disukai panelis adalah sari kulit buah manggis dengan $\mathrm{pH} 3$ dan suhu pasteurisasi $75^{\circ} \mathrm{C}$. Untuk meningkatkan tingkat kesukaan panelis terhadap sari kulit buah manggis dengan $\mathrm{pH}$ 4, dapat menambahkan pewarna alami seperti rosela. Rosela mengandung pigmen alami antosianin yang menghasilkan warna merah. ${ }^{22}$ Penambahan rosela diharapkan dapat meningkatkan warna merah pada sari kulit buah manggis.

b. Aroma

Variasi $\mathrm{pH}$ dan suhu pasteurisasi tidak mempengaruhi tingkat kesukaan panelis terhadap aroma sari kulit buah manggis. Semua variasi $\mathrm{pH}$ dan suhu pasteurisasi terhadap warna sari kulit buah manggis disukai panelis. Aroma dari keenam sari kulit buah manggis tidak terlalu tajam. Hal ini dikarenakan aroma sari kulit buah manggis dapat hilang menguap selama pasteurisasi, sehingga aroma sari kulit buah manggis tidak terlalu tajam. ${ }^{23}$ Selain itu, aroma asam pada sari kulit buah manggis juga tidak terlalu tajam. Hal ini dikarenakan nilai $\mathrm{pH}$ awal sari kulit buah manggis adalah 4,28-4,42, sehingga penambahan asam sitrat pada sari kulit buah manggis tidak terlalu banyak, yaitu sari kulit buah manggis dengan $\mathrm{pH} 3$ sebanyak $23,5 \mathrm{ml}$ dan sari kulit buah manggis dengan $\mathrm{pH} 4$ sebanyak $2,5 \mathrm{ml}$ (larutan asam sitrat dengan konsentrasi $10 \%)$.

c. Rasa

Sari kulit buah manggis memiliki rasa manis, asam, dan after taste yaitu sepat. Rasa asam pada sari kulit buah manggis tidak terlalu tajam. Hal ini dikarenakan penambahan asam sitrat tidak terlalu banyak. Berdasarkan hasil pengukuran kulit buah manggis memiliki 
$\mathrm{pH}$ yang asam yaitu 4.28-4.42, sehingga pada perlakuan $\mathrm{pH} 3$ dan 4 hanya memerlukan penambahan larutan asam sitrat dengan konsentrasi $10 \%$ sebanyak $23.5 \mathrm{ml}$ dan $2.5 \mathrm{ml}$. Semua sampel sari kulit buah manggis memiliki after taste yaitu rasa sepat. Namun, rasa sepat dari sari kulit buah manggis dengan $\mathrm{pH} 4$ dan suhu $95^{\circ}$ masih dapat ditoleransi panelis. Adanya rasa sepat pada sari kulit buah manggis ini disebabkan adanya tanin. Tanin pada kulit buah manggis diduga merupakan golongan tanin terkondensasi. Istilah tanin yang digunakan dalam bidang pangan ada dua macam, yaitu tanin terkondensasi dan tanin terhidrolisa. Tanin terkondensasi merupakan polimer dari katekin dan leukoantosianin. Senyawa tanin terkondensasi tidak dapat dihirolisa baik oleh asam, basa, maupun enzim. Sedangkan, tanin terhidrolisa terdiri dari senyawa poliester dan glikosida yang satu sama lainnya dihubungkan oleh atom $\mathrm{O}$ dan mudah terhidrolisis dengan asam dan enzim. ${ }^{12}$ Oleh karena itu, pengasaman tidak dapat menurunkan kadar tanin pada sari kulit buah manggis. Namun, tanin mempunyai sifat dapat berikatan dengan protein (albumin). Penggunaan protein dapat menurunkan kadar tanin sehingga dapat mengurangi rasa sepat pada sari kulit buah manggis. ${ }^{12}$ Pengasaman $\mathrm{pH} 3$ hanya mampu menyelubungi rasa sepat di awal saja, tetapi tetap meninggalkan after taste yaitu rasa sepat yang tajam.

Rasa sepat pada sari kulit buah manggis dengan suhu $95^{\circ} \mathrm{C}$ tidak terlalu tajam dibandingkan dengan sari kulit buah manggis dengan suhu $75^{\circ} \mathrm{C}$ dan $85^{\circ} \mathrm{C}$. Hal ini dikarenakan kadar tanin dapat berkurang oleh pemanasan, namun pemanasan tidak dapat menghilangkan semua tanin, sehingga masih meninggalkan rasa sepat. $^{24}$ Dalam penelitian ini, suhu pasteurisasi lebih berpengaruh terhadap penurunan tanin pada sari kulit buah manggis daripada pengasaman. Suhu pasteurisasi secara tidak langsung juga mempengaruhi rasa pada sari kulit buah manggis. Suhu yang tinggi dan suasana asam akan memecah antosianin menjadi antosianidin dan glukosa. $^{12} \mathrm{Hal}$ ini diduga dapat menyebabkan rasa manis dari sari kulit buah manggis bertambah dan rasa sepat tidak terlalu mendominasi sari kulit buah manggis.

\section{SIMPULAN}

1. Sari kulit buah manggis dengan $\mathrm{pH} 4$ dan suhu pasteurisasi $85^{\circ} \mathrm{C}$ memiliki aktivitas antioksidan paling tinggi yaitu $89.70 \%$.

2. Warna sari kulit buah manggis dengan $\mathrm{pH}$ 3 dan suhu pasteurisai $75^{\circ} \mathrm{C}$ paling disukai oleh panelis. Semakin asam $\mathrm{pH}$ sari kulit buah manggis, warna sari kulit buah manggis makin disukai panelis.

3. Aroma sari kulit buah manggis yang dihasilkan tidak tajam. Variasi $\mathrm{pH}$ dan suhu pasteurisasi tidak mempengaruhi aroma sari kulit buah manggis.

4. Pengasaman tidak dapat menghilangkan rasa sepat pada sari kulit buah manggis. Namun, sari kulit buah manggis dengan pH 4 dan suhu pasteurisasi $95^{\circ} \mathrm{C}$ disukai oleh panelis dan rasa sepat dapat ditoleransi panelis.

\section{SARAN}

1. Sari kulit buah manggis yang direkomendasikan pada pembaca adalah sari kulit buah manggis dengan $\mathrm{pH} 4$ dan suhu pasteurisasi $95^{\circ} \mathrm{C}$. Berdasarkan AKG vitamin $\mathrm{C}$, sari kulit buah manggis yang disarankan untuk dikonsumsi anak-anak dan dewasa yaitu sebanyak $225 \mathrm{ml}$ dan $300 \mathrm{ml}$.

2. Pewarna alami seperti rosela dapat ditambahkan untuk meningkatkan warna kemerahan pada sari kulit buah manggis dengan $\mathrm{pH} 4$.

3. Perlu penelitian lebih lanjut untuk mengetahui penurunan kadar tanin dengan penggunaan bahan - bahan penurun tanin lainnya seperti protein albumin maupun gelatin.

\section{DAFTAR PUSTAKA}

1. Erik Tapan. Kanker, Antioksidan, dan Terapi Komplementer. Jakarta: Gramedia; 2005. p.103-104, 187-15.

2. Departemen Kesehatan Republik Indonesia. Laporan Hasil Riset Kesehatan Dasar (RISKESDAS) Indonesia tahun 2007. Jakarta : Badan Penelitian dan Pengembangan Kesehatan; 2008.

3. Mayes PA. Struktur dan Fungsi Vitamin LarutLipid. In: Murray RK, Granner DK, Mayes PA, Rodwell VW, editors. Biokimia Harper. 
25th ed. Jakarta: Penerbit Buku Kedokteran EGC; 2003. p.619-20.

4. Prior RL. Fruits and Vegetables in the Prevention of Cellular Oxidative Damage. American Journal Clinical Nutrition 2003; 78(suppl) : 570S-8S.

5. Weecharangsan W, Opanasopit P, Sukma M, Ngawhirunpat T, Sotanaphun U, Siripong P., Antioxidative and neuroprotective activities of extracts from the fruit hull of mangosteen (Garcinia mangostana Linn.), Medical Principle Practtice 2006; 15:281-87.

6. Asep W. Permana. Kulit Buah Manggis dapat menjadi Minuman Instan Kaya Antioksidan. Warta Penelitian dan Pengembangan Pertanian 2010; 32(2): 5-7.

7. Moongkarndi $\mathrm{P}$, Kosem $\mathrm{N}$, Kaslungka S, Luanratana O, Pongpan N, Neungton N., Antiproliferation, antioxidation and induction of apoptosis by Garcinia mangostana (mangosteen) on SKBR3 human breast cancer cell line. Journal Ethnopharmacol 2004; 90(1):161-66.

8. Masniari Poeloengan dan Praptiwi. Uji Aktivitas Antibakteri Ekstrak Kulit Buah Manggis (Gracinia mangostana Linn). Media Litbang Kesehatan 2010; 20(2): 65-9.

9. Jiang DJ, Dai Z, Li YJ. Pharmacological Effects of Xanthones as Cardiovascular Protective Agents. Cardiovascular Drug Reviews. 2004; 22(2): 91-02

10. Made Astawan dan Andreas Leomitro Kasih. Khasiat Warna - Warni Makanan. Jakarta: Gramedia; 2008. p.31-10.

11. Suyanti. Panduan Mengolah 20 Jenis Buah. Jakarta: Penebar Swadaya; 2010. p.51-58.

12. F.G. Winarno. Kimia Pangan dan Gizi. Jakarta: Gramedia; 2002. p.24-5, 221.

13. Wiwik Wijayaningsih, Arintina Rahayuni, Sri Hetty Susetyorini. Daya Antiseptik, Kadar Vitamin C, Kadar Tanin dan Daya Terima Sari Buah Jambu Monyet (Anacardium occidentale) Pada Jenis Jambu dan Variasi Pengolahan. Jurnal Link 2010 ; 6(1): 72-79.

14. Wisnu Cahyadi. Analisis dan Aspek Kesehatan Bahan Tambahan Pangan. Jakarta: Bumi Aksara; 2009. p.61-93.

15. Clifford MN. Anthocyanins-nature, occurrence and dietary burden. Journal of the Science of Food and Agriculture 2000; 80. 1063-72.

16. Molyneux Philip. The Use of Stable Free Radical diphenylpicryl-hydrazyl (DPPH) for Estimating Antioxidant Activity. Songklanakarin J. Sci. Technol., 2004, 26(2) : 211-219.

17. Jung HA, Su BN, Keller WJ, Mehta RG, Kinghorn AD. Antioxidant xanthones from the pericarp of Garcinia mangostana
(Mangosteen). Journal Agriculture Food Chemical 2006; 54(6): 2077-82.

18. Efri Mardawati, Cucu S. Achyar, Herlina Marta. Kajian Aktivitas Antioksidan Ekstrak Kulit Manggis (Garcinia mangostana L.) Dalam Rangka Pemanfaatan Limbah Kulit Manggis di Kecamatan Puspahiang Kabupaten Tasikmalaya. Laporan Akhir Penelitian Peneliti Muda Universitas Padjadjaran. 2008.

19. Roobha JJ, Saravanakumar M, Aravindhan K, Devi PS. The Effect of Light, Temperature, $\mathrm{pH}$ on stability of anthocyanin pigment in Musa acuminata bract. Research in Plant Biology 2011; 1(5): 05-12.

20. Setyaningrum Ariviani. Total Antosianin Ekstrak Buah Salam Dan Korelasinya Dengan Kapasitas Anti Peroksidasi Pada Sistem Linoleat. AGROINTEK 2010; 4(2): 121-26.

21. Rein Maarit. Copigmentation Reactions and Color Stability of Berry Anthocyanins [dissertation]. Faculty of Agriculture and Forestry: University of Helsinki; 2005.

22. Poppy Suryaatmaja W dan Anne Nelistya. Rosella. Jakarta : penebar swadaya. 2008.

23. Fellows P. Food Processing Technology Principles and Practice Second Edition. New York: CRC Press; 2000. p.241-49.

24. Anbreen S, Iqbal N, Bhatty N, Musaddique M. Effect Of Soaking, Heating And Autoclaving On Tannin And Protein Contents Of Chickpea. Pah. J. ut Agri. Sci. 1999; 36(1-2): 63-66. 